\title{
РЕАЛІЗАЦІЯ ПРИНЦИПУ ТЕКСТОЦЕНТРИЗМУ В ПРОЦЕСІ ФОРМУВАННЯ КОМУНІКАТИВНИХ УМІНЬ І НАВИЧОК УЧНІВ
}

Цоуфал Л. С. Реалізація принципу текстоцентризму в процесі формування комунікативних умінь і навичок учнів.

Статтю присвячено проблемі формування комунікативних умінь і навичок учнів на основі тексту. Автор обгрунтовує необхідність реалізації принципу текстоцентризму в процесі навчання української мови, розкриває дидактичні можливості тексту для розвитку мовлення школярів, характеризує аналіз тексту як ефективний прийом формування умінь і навичок спілкування.

Ключові слова: комунікативно-діяльнісний підхід, текстоцентричний принцип, текст, комунікативні уміння й навички.

Цоуфал Л. С. Реализация принципа текстоцентризма в процессе формирования коммуникативных умений и навыков учащихся.

Статья посвящена проблеме формирования коммуникативных умений и навыков учащихся на основе текста. Автор обосновывает необходимость реализации принципа текстоцентризма в процессе обучения украинскому языку, раскрывает дидактические возможности текста для развития речи школьников, характеризует анализ текста как эффективный приём формирования умений и навыков общения.

Ключевые слова: коммуникативно-деятельный подход, текстоцентрический принцип, текст, коммуникативные умения и навыки.

Tsoufal L. S. Realization of principle of textocentrism in the process of forming of communicative skills and habits.

The article is devoted to a problem of communicative skills and habits formation of the pupils on the basis of the text. The author proved the necessity of realization of textocentrism principle in the process of teaching of Ukrainian language, the didactical possibilities of text for developing the pupils' speech, the analysis of text as an effective way for forming skills and habits of speech is also characterized in the article.

Key words: communicative-functional way, textocentrism principle, text, communicative skills and habits.

Нові аспекти навчання рідної мови визначаються тими функціями, які виконує українська мова в сучасному суспільстві. Розробка нової стратегії освіти передбачає компетентнісно зорієнтоване навчання, спрямоване на формування в учнів якостей, необхідних людині в будь-якій сфері діяльності, у будь-якій життєвій ситуації.

Одним із завдань реформування змісту мовної освіти є вироблення на основі державних стандартів системи знань про мову й мовлення, мовних і мовленнєвих умінь та навичок, досвіду творчої діяльності й емоційноціннісного ставлення до світу, переорієнтація процесу навчання на розвиток особистості учня, формування його компетентностей. 
Посилення уваги до мовленнєвого розвитку, до формування комунікативної компетенції учнів - суттєва особливість сучасного освітнього процесу. Мовленнєвий розвиток визначено і як мету, і як засіб навчання.

У сучасній лінгводидактиці обстоюється думка, згідно з якою показником високого рівня мовної освіти, крім орфографічно-пунктуаційної грамотності, є вміння спілкуватися, використовуючи відповідно до потреб комунікації фонетичне, лексичне багатство, різноманітні синтаксичні конструкції, стилістичні можливості рідної мови. Тому одним із головних завдань навчання мови $є$ формування у школярів умінь і навичок комунікативно виправдано користуватися засобами мови в різних життєвих ситуаціях під час сприймання, відтворення і створення висловлювань 3 дотриманням українського мовленнєвого етикету.

Провідними в навчанні мови на сучасному етапі методисти (3. Бакум, О. Горошкіна, Т. Донченко, С. Караман, А. Нікітіна, С. Омельчук, М. Пентилюк, Г. Шелехова) визначають комунікативно-діяльнісний, особистісно зорієнтований, соціокультурний і компетентнісний підходи.

Підхід як напрям у навчанні характеризують ті чи ті принципи, що умовлюють пріоритетні особливості навчального процесу, детермінують його зміст, уможливлюють доцільний вибір методів і прийомів навчання. У теорії та практиці навчання мовлення важливо реалізувати загальнодидактичні та лінгводидактичні (загальнометодичні і специфічні) принципи навчання. До загальнометодичних принципів науковці традиційно відносять: взаємозалежність мови і мислення, екстралінгвістичний, функційний, міжпредметного та внутрішньопредметного зв'язку, зв'язок навчання двох (кількох) мов, історичний, взаємозалежність усного і писемного мовлення.

3. Бакум запропонувала до загальнометодичних принципів додати текстоцентричний, який передбачає визнання тексту як найважливішої одиниці в навчанні рідної мови, може реалізовуватися в таких напрямках: текст $є$ засобом пізнання мови як поліфункційного явища; текст виступає найважливішим засобом долучення до української культури; навчання мови здійснюється на основі тексту як одиниці мови, завдяки якій відбувається пізнання мовних явищ та засобів, формується система мовних понять; текст виступає як мовленнєвий витвір, результат використання системи мови, оскільки на його засадах вивчають мову в дії, засвоюють закономірності функціонування мовних засобів у мовленні; текст - основний засіб оволодіння усною та писемною формами українського мовленням, оволодіння мовленнєвою діяльністю у всіх іiі видах (читання, говоріння, аудіювання, письмо), він є підгрунтям формування комунікативної компетенції; текст є засобом створення ситуацій, за допомогою яких здійснюється реальне спілкування [1, 142].

Упровадження сучасних підходів у навчанні можливе за умови використання текстової основи дидактичного матеріалу, оскільки текст є носієм 
інформації, засобом пізнання довкілля, формування в учнів національномовної картини світу.

Комунікативно-діяльнісний підхід у навчанні мови полягає в такій організації навчання, коли засвоєння мови відбувається безпосередньо в процесі комунікативної діяльності з метою оволодіння комунікативними уміннями і навичками, забезпечує підготовку учнів до ефективної взаємодії в різних сферах суспільного життя.

Комунікативні уміння і навички формуються під час роботи над зв'язним мовленням на основі аналізу текстів-зразків та конструювання власних висловлювань в усній і писемній формі. На текстах-зразках учитель може продемонструвати зміст і структуру спілкування, ознайомити учнів з мовними і позамовними засобами.

До комунікативних умінь, якими повинні оволодіти учні, віднесено:

- уміння правильно визначати тему висловлювання і чітко дотримуватися ії меж;

- будувати висловлювання відповідно до мети, основної думки та адресата мовлення;

- використовувати найбільш вагомі факти і докази для розкриття теми і основної думки висловлювання;

- будувати висловлювання логічно і послідовно (встановлювати причинно-наслідкові зв'язки між фактами та явищами, робити необхідні узагальнення й висновки);

- вибирати тип і стиль мовлення залежно від мети і ситуації спілкування;

- використовувати різноманітні мовні засоби відповідно до типу, стилю, жанру висловлювання;

- удосконалювати висловлювання (коректувати усне й редагувати писемне) $[4,37]$.

Комунікативно-діяльнісний підхід потребує розгляду лінгвістичної теорії як інструмента для практичного оволодіння мовою, передбачає цілеспрямовану організацію навчання школярів усім видам мовленнєвої діяльності, створення на уроці таких умов, які б спонукали учнів спілкуватися, висловлювати свої думки, доводити власні переконання, впливати на співрозмовників $[6,71]$.

Робота над формуванням комунікативних умінь і навичок, якою б простою чи складною вона не була, у своїй основі є роботою над змістом тексту, його логічною структурою і мовним оформленням. Уміння переказувати готовий текст $\epsilon$ початковим етапом роботи над змістом висловлювання. Підготовка власних висловлювань супроводжується роботою над планом, структурою та їхнім мовним оформленням. У процесі роботи над текстом передбачається, що він буде використовуватися, з одного боку, як носій певної суспільно і особистісно значущої інформації, як засіб виховного впливу вчителя на учнів; а з іншого - як об’єкт виявлення в ньому лі- 
нгвістичних явищ і фактів та організації спостереження над ними, щоб школярі оволоділи не лише змістовою стороною мовленнєвої діяльності, а й мали системні знання, які стосуються їі формальної сторони. Саме на рівні тексту відбувається 3'ясування семантики слова, його понятійних зв'язків, усвідомлення синтаксичної диференціації, моделювання зв'язного висловлювання. Т. Донченко зазначає, що вивчення мови на текстовій основі вносить в уроки мови необхідний емоційний компонент, дає змогу показати мовні засоби в системі з іншими в живому мовленні, поєднати вивчення мовних одиниць з розв'язанням комунікативних завдань.

Для методики навчання рідної мови актуальною є проблема співробітництва вчителя й учнів у навчанні, що визначає суб'єктами навчального процесу і того, хто навчає, і того, хто навчається. Педагогіка співробітництва передбачає обов'язкову активність педагога й учнів. У навчальному діалозі максимально реалізується взаємодія в системі «вчитель - учні учень». Така взаємодія забезпечує не тільки розвиток пізнавальної активності та творчого потенціалу кожного учня, а й підвищення рівня професійної майстерності вчителя як організатора навчального діалогу.

Участь у навчальному діалозі вимагає від учителя й учнів орієнтації: 1) у ситуації спілкування на етапі формулювання мети і завдань навчання, їхньої мотивації та послідовному виконанні в спільній навчальній діяльності; 2) у ситуації спілкування на основі предметного змісту і методики навчання з використанням цікавого, пізнавального матеріалу, додаткової літератури, нових технологій навчання $[2,6]$.

Розв'язати названі завдання можливо, якщо засадничим принципом опанування мови є робота з текстом.

Текст можна назвати навчальним, якщо він відповідає науковометодичним вимогам, що забезпечують: 1) мотиваційну готовність учня (спрямованість на вирішення певної комунікативної задачі, наявність позиції мовця, виразність, емоційне забарвлення, зверненість); 2)смислову структуру й адекватність розуміння тексту (зв'язність, цілісність, логічність, інформативність); 3) індивідуалізоване сприйняття тексту (урахування вікових інтересів учнів на основі інформативності, урахування рівня розвитку учнів); 4) безпосереднє удосконалення мовленнєвих навичок на основі тексту (невеликий обсяг тексту, відсутність незасвоєного мовленнєвого матеріалу, трансформація нового матеріалу на основі вивченого раніше, уведення мовленнєвого матеріалу в систему різноманітних зв'язків, повторюваність матеріалу) [5, 189].

Такий текст допомагає учням засвоїти мовленнєвознавчу теорію не тільки як певні поняття і формулювання, але й уміння виконувати навчальні дії з цими поняттями, тобто сприяє розвитку мовлення учнів і формуванню в них навичок спілкування.

Як зазначає В. Мельничайко, використовувані на уроках тексти, як правило, мають бути бездоганними з погляду їх побудови, відзначатися ба- 
гатством лексики, різноманітністю синтаксичних конструкцій, чіткістю i виразністю. Тільки в цьому випадку вони можуть служити зразком для наслідування [3, 120].

Робота з розвитку мовлення школярів забезпечує зв'язок мовної теорії 3 практичним іï використанням під час опрацювання і самостійного створення текстів різних типів, стилів і жанрів мовлення. Аналіз текстів під час проведення переказів різних видів і в процесі підготовки до написання творів передбачає такі етапи: визначити тему та основну думку тексту; виділити абзаци або мікротеми; визначити стиль і тип мовлення, структурні елементи тексту; з'ясувати мовні засоби (лексичні, граматичні, стилістичні), засоби зв'язку речень у тексті, які вживаються для забезпечення його змістової цілісності.

В основу формування комунікативних умінь та навичок покладено сукупність понять 3 лінгвістики тексту, стилістики і теорії мовленнєвої діяльності. Відомості про текст, його структуру, особливості, передбачені чинними програмами з рідної мови, забезпечують формування комунікативної компетенції учнів, умінь будувати усні й писемні висловлювання, спілкуватися в різних життєвих ситуаціях. Реалізація принципу текстоцентризму сприяє удосконаленню не тільки мовленнєвої, але й мисленнєвої діяльності школярів.

\section{Література}

1. Бакум 3. П. Теоретико-методичні засади навчання фонетики української мови в гімназії: [монографія] / 3. П. Бакум. - Кривий Ріг : Видавничий дім, 2008. - 338 с.

2. Лобко-Лобановська Н. А. Робота з навчальним текстом на уроці: [посібник для вчителів російської мови та студентів-філологів педвузів] / Н. А. ЛобкоЛобановська. - Х. : Видав. гр. «Основа», 2003. - 96 с.

3. Мельничайко В. Я. Лінгвістичні основи викладання української мови в школі / В. Я. Мельничайко // Мовознавство і школа. - К. : Наукова думка, 1981. С. $22-123$.

4. Методика навчання рідної мови в середніх навчальних закладах: [підручник для студентів-філологів] / за ред. М. І. Пентилюк - К. : Ленвіт, 2000. - 264 с.

5. Пассов Е. И. Коммуникативный метод обучения иноязычному говорению / Е. И. Пассов. - М. : Просвещение, 1991. - 223 с.

6. Словник-довідник з української лінгводидактики: [навчальний посібник] / за ред. М. Пентилюк. - К. : Ленвіт,2003. - 149c.

7. Шелехова Г. Особливості технології уроків з розвитку мовлення в 6 класі (за новою програмою) / Г. Шелехова // Українська мова і література в школі. 2004. - №2. - C. 13-18. 